\title{
UJI STABILITAS FISIK SECARA ORGANOLEPTIS PEMBUATAN SEDIAAN MINYAK GOSOK DARI BAHAN KELAPA (Cocos nucifera L.), SERAI (Cymbopogon citratus DC.) DAN DAUN JERUK NIPIS (Citrus aurantifolia)
}

\author{
Susi Andriani ${ }^{*}$, Ebih Sulisiyanti ${ }^{2}$ \\ 1,2Sekolah Tinggi Ilmu Kesehatan Holistik Purwakarta \\ *Korespondensi: Jl. Veteran No. 272 Ciseureuh Purwakarta, Email: susi_andriani08@yahoo.co.id
}

\begin{abstract}
ABSTRAK
Latar Belakang : Virgin Coconut Oil (VCO) dari minyak kelapa murni saat ini banyak dimanfaatkan masyarakat sebagai obat gosok, Pencampuran VCO sebagai minyak gosok dengan penambahan batang serai dan daun jeruk nipis dapat menambah khasiat dan kegunaannya.

Tujuan : Penelitian ini bertujuan untuk melihat kestabilan minyak gosok setelah 4, 6 dan 8 minggu pada wadah tertutup serta menyediakan sediaan praktis dari bahan alam yang dapat digunakan oleh masyarakat dengan teknik pembuatan yang mudah, murah dan praktis.

Metode : Penelitian ini merupakan penelitian deskriptif yang sebelumnya telah digunakan secara turun-temurun. Pembuatan dilakukan melalui proses pengendapan selama empat hari dengan menggunakan pelarut air. Minyak gosok dibuat dengan bahan kelapa satu kilogram yang diparut dan ditambahkan air sebanyak satu liter untuk dua kali perasan, didapat santan sebanyak $1000 \mathrm{ml}$ lalu santan disaring, hasil saringan endapkan selama tiga hari menghasilkan minyak kelapa murni sebanyak $400 \mathrm{ml}$, setalah menjadi minyak kelapa murni (VCO) ditambahkan serai (Cymbopogon citratus DC.) sebanyak 25gram dan daun jeruk nipis (Citrus aurantifolia.) 25gram yang sudah dipotong-potong diendapkan selama satu hari kemudian disaring dan menghasilkan minyak gosok dibuat 3 botol dengan masing-masing berat $100 \mathrm{ml}$.

Hasil : Pengujian organoleptis sediaan dilakukan selama 4, 6 dan 8 minggu dengan hasil yang menunjukan bahwa tidak ada pertumbuhan jamur maupun perubahan negatif yang terjadi secara fisik dari warna, rasa, dan bentuk konsistensinya, sedangkan untuk bau pada minyak gosok mengalami pengurangan bau serai dan jeruk nipis. Hal ini dapat dikatakan bahwa dalam waktu 8 minggu minyak gosok dapat digunakan secara aman.
\end{abstract}

Simpulan : Sediaan minyak gosok sebagai perawatan pada kesehatan kulit dengan pengujian organoleptis selama 8 minggu dapat digunakan secara aman.

Kata kunci : Virgin Coconut Oil (VCO), serai, jeruk nipis, minyak gosok

\begin{abstract}
Background: Virgin Coconut Oil (VCO) from pure coconut oil is now widely used by the community as a liniment, mixing VCO as an abrasive oil with the addition of lemongrass and lime leaves can add to its usefulness and usefulness.

Objective: This study aims to see the stability of scrub oil after 4, 6 and 8 weeks in sealed containers as well as to provide practical preparations of natural materials that can be used by people with easy, cheap and practical manufacturing techniques.

Methods: This is a descriptive study that has been used for generations. The preparation is carried out through a four-day deposition process using a water solvent. Rubbing oil is made with one kilogram of coconut which is shredded and added one liter of water for two squids, the coconut milk is obtained $1000 \mathrm{ml}$ and the filter is filtered, the filter for three days produces $400 \mathrm{ml}$ of pure coconut oil, after the pure coconut oil (VCO) added lemongrass (Cymbopogon citratus DC.) as much as $25 \mathrm{gram}$ and lime leaves (Citrus aurantifolia.) 25grams that have been cut into pieces for one day then filtered and yielded a rubbing oil made 3 bottles with each weight $100 \mathrm{ml}$.

Result: The organoleptic test of the preparation was carried out for 4, 6 and 8 weeks with the result showing that there was no fungal growth and physical changes that occurred physically from the color, flavor, and consistency shape, while for the odor of the rubbing oil had decreased the smell of lemongrass and orange nipis. It can be said that within 8 weeks the rubbing oil can be used safely.
\end{abstract}


Conclusion: The preparation of abrasive oil as a treatment of skin health by organoleptic testing for 8 weeks can be used safely.

Keywords: Virgin Coconut Oil (VCO), lemongrass, lime, ointment

\section{PENDAHULUAN}

Penggunaan bahan alam berupa tumbuhan di Indonesia telah banyak berkembangterutama dalam hal teknologi pembuatannya. Dewasa inikonsep "back to nature" telah mendapat perhatian masyarakat seiring bertambahnya informasi mengenai khasiat tanaman untuk pengobatan ${ }^{1}$. Beberapa industri herbal mengembangkan teknologi pembuatan sediaan herbaldengan berbagai kemasan yang mudah diperoleh di toko-toko maupun apotek. Di beberapa tempat masih banyak masyarakat membuat sediaan obat herbal secara tradsional misalnya dengan membuat obat gosok, parem, pilis, tapel maupun lulur dengan cara-cara yang sederhana, murah dan mudah. Dalam hal ini pembuatan minyak gosok lebih praktis, sehingga banyak masyarakat tertarik untuk membuatnya. Namun karena sediaan ini masih dibuat secara tradisional maka belum dapat dipastikan kestabilan dan waktu kadaluarsanya, sehingga perlu adanya uji organoleptis untuk mengukur dan melihat, rasa, warna, bau dan bentuk minyak gosok dengan bahan dasar minyak kelapa murni atau Virgin Coconut Oil (VCO).

Pohon kelapa sangat bermanfaat bagi kehidupan manusia karena hampir semua bagian kelapa dapat dimanfaatkan. Selain itu kelapa juga menghasilkan produk olahan yang popular belakangan ini yaitu VCO yang bermanfaat bagi kehidupan manusia. Minyak kelapa murni adalah produk herbal yang banyak mendapat perhatian masyarakat dengan segudang manfaat bagi kesehatan tubuh.Pembuatan minyak gosok tidak lagi hanya menggunakan 1 jenis tanaman yaitu minyak kelapa sebagai bahan bakunya, namun untuk menambah khasiat dan manfaat minyak gosok ini maka dibuatlah suatu minyak gosok yaitu VCO yang dikombinasikan dengan daun serai untuk khasiat analgetik (pengurang rasa sakit) pada saat kerik/gosok, maupun karena gigitan serangga ${ }^{2}$.Penambahan daun jeruk nipis sebagai antioksidan pada pembuatan minyak gosok dapat berkhasiat dalam pemeliharan kulit, selain ituuntuk melembabkan kulit kering dan pecah-pecah ${ }^{3}$.

Dengan bertambahnya khasiat pada sediaan minyak gosok ini maka sangat penting untuk mengetahui batas waktu pemakaian sediaan ini. Sehingga sediaan dapat memiliki khasiat yang maksimal ketika digunakan sebagai pengobatan maupun pemeliharaan kesehatan. Berdasarkan hal tersebut diperlukan adanya uji stabilitas fisik pada sediaan minyak gosok ini.

Untuk menguji stabilitas fisik salah satunya dapat dilakukan secara organoleptis yaitu dengan mengamati sediaan minyak gosok dengan menggunakan panca indera sebagai alat pengamatan yaitu meliputi rasa, warna, bau dan bentuk. Uji organoleptik memiliki relevansi yang tinggi dengan mutu produk karena berhubungan langsung dengan selera konsumen ${ }^{4}$.

Indra peraba yang berkaitan dengan struktur, tekstur dan konsistensi. Struktur merupakan sifat dari komponen penyusun, tekstur merupakan sensasi tekanan yang dapat diamati dengan mulut atau perabaan dengan jari, dan konsistensi merupakan tebal, tipis dan halus.Indra pembau, pembauan juga dapat digunakan sebagai suatu indikator terjadinya kerusakan pada produk, misalnya ada bau busuk yang menandakan produk tersebut telah mengalami kerusakan. Indra pengecap, dalam hal kepekaan rasa, maka rasa manis dapat dengan mudah dirasakan pada ujung lidah, rasa asin pada ujung dan pinggir lidah, rasa asam pada pinggir lidah dan rasa pahit pada bagian belakang lidah ${ }^{4}$.

Dalam hal ini uji organoleptis yang dilakukan akan menilai kestabilan fisik minyak gosok dalam rentang waktuselama 4 minggu, 6 minggu dan 8 minggu pada wadah terbuka dan wadah tertutup, sehingga dapat dilihat apakah perbedaan pada wadah dapat mempengaruhi stabilitas minyak gosok. Selain ituapakah terjadi perubahan pada warna, rasa, bau dan bentuk sehingga dapat ditentukan apakah minyak gosok ini masih layak untuk dapat digunakan sebagai pengobatan maupun pemeliharaan 
kesehatan serta tidak menimbulkan efek samping yang berbahaya dalam rentang waktu tersebut.

Hal ini dilakukan karena sediaan minyak gosok ini tidak menggunakan bahan-bahan kimia maupun pengawet. Kestabilan suatu sediaan merupakan hal yangharus diperhatikan dalam membuat suatu formulasi sediaan farmasi herbal. Selain itu merupakan sesuatu yang penting mengingat sediaan biasanya diproduksi dalam jumlah besar dan memerlukan waktu yang cukup panjang untuk sampai ke tangan konsumen. Sehingga penelitian ini bertujuan untuk mengetahui stabilitas sediaan minyak gosok secara organoleptis yaitu mengenai rasa, warna, bau dan bentuk sediaan dalam kurun waktu 4 minggu, 6 minggu dan 8 minggu serta diharapkan minyak gosok ini selain dapat digunakan sebagai pengobatan keluarga, dapat juga menambah nilai ekonomi untuk meningkatkan kesejahteraan keluarga.

\section{METODE}

Metode yang dilakukan pada penelitian ini adalah menggunakan metode deskriptif. Menurut Hidayat Syah penelitian deskriptif adalah metode penelitian yang digunakan untuk menemukan pengetahuan yang seluas luasnya terhadap objek penelitian pada suatu masa tertentu, hampir sama dengan yang dikemukakan Sukmadinata tahun 2006 yang menjelaskan bahwa penelitian deskriptif adalah suatu bentuk penelitian yang ditujukan untuk mendeskripsikan fenomena-fenomena yang ada baik berupa bentuk, perubahan, hubungan, kesamaan dan perbedaan fenomena yang satu dengan yang lain ${ }^{5}$.

Dalam hal ini penelitian yang dilakukan bertujuan untuk menjelaskan uji stabilitas fisik secara organoleptis yaitu rasa, warna, bau dan bentuk dari karateristik minyak gosok yang terbuat dari VCO, daun serai dan daun jeruk nipis.Minyak gosok ini dibuat dalam 3wadahmasing-masing untuk sediaan selama 4 minggu, 6 minggu dan 8 minggu.

Pemilihan waktu pengamatan didasarkan pada hasil penelitian Rickson Tanka 2016 bahwa penggunaan minyak gosok untuk 3 minggu masihmemiliki stabilitas sediaan yang masih dalam keadaan baik apabila dilihat secara fisik yaitu berdasarkan rasa, warna, bau dan bentuk ${ }^{2}$.

Penelitian ini dimaksudkan untuk mengetahui cara pembuatan sediaan tradisional dari herbal dengan bahan baku Cocos nucifera L. (kelapa) yang digabungkan dengan Cymbopogon citratus DC. (serai) dan Citrus aurantifolia (daun jeruk nipis) yang dibuat menjadi sediaan minyak gosok dengan metode pengendapan secara tradisional dan sudah dilakukan secara turun temurun. Tahap selanjutnya dilakukan uji stabilitas fisik secara organoleptis yang meliputi rasa, warna, bau dan bentuk. Ada beberapa langkah yang harus dilakukan seperti pengumpulan bahan, pembuatan sediaan menjadi minyak gosok dan pengamatan sediaan selama 4 minggu, 6 minggu dan 8 minggu.

Sebelum dilakukan pembuatan sediaan minyak gosok, Pembuatan minyak kelapa murni (VCO) dengan bahan dasar kelapa $1 \mathrm{~kg}$ dengan informasi kelapa diparut, lalu disaring dan endapkan setelah sudah menjadi minyak kelapa murni, tambahkan batang serai yang sudah dipotong halus sebanyak 30 gram dan daun jeruk nipissebanyak 30 gram kedalam minyak kelapa murni lalu diendapkan lagi dan menjadi minyak gosok.

\section{HASIL}

\section{Penyiapan bahan}

Menggunakan kelapa yang sudah tua artinya dagingnya sudah siap untuk digunakan sebagai bahan baku untuk pembuatan minyak kelapa murni, serai yang diambil dipastikan masih berwarna hijau tidak berwarna coklat atau kekuningkuningan karena serai yang masih hijau menunjukan serai masih segar, sedangkan untuk pembuatan minyak gosok diperlukan serai yang aromanya masih menyengat, sedangkan untuk daun jeruk nipis pemilihannya hampir sama dengan serai dipilih daun yang masih segar yang tidak layu.

\section{PEMBAHASAN}

Minyak gosok virgin coconut oildibuat menjadi 3 kelompok uji yaitu untuk 4 minggu, 6 minggu dan 8 minggu diuji secara organoleptis menurut rasa, bau, warna dan bentuk. Dari hasil penelitian, pembuatan 
minyak gosok dari bahan kelapa, serai, dan daun jeruk nipis membutuhkan waktu selama empat hari pengendapan minyak kelapa murni setelah itu ditambahkan potongan halus batang serai dan daun jeruk nipis ke dalam minyak kelapa murni yang sudah jadi selama satu hari. Pada proses pengendapan minyak kelapa murni (virgin coconut oil) yang diproses selama 4 hari dan secara tradisional dengan alat-alat sederhana tanpa zat tambahan terlihat ada 3 lapisan pada hasil pengendapan, lapisan paling atas berwarna putih seperti krim putih

Minyak kelapa murni (virgin coconut oil) menggunakan pelarut air matang yang ditambahkan kedalam daging kelapa yang sudah diparut lalu diperas untuk menghasilkan santan dengan proses yang singkat dengan tujuan agar minyak kelapa murni tidak berbau tengik. Minyak kelapa murni (virgin coconut oil) yang kandungan asam lemak jenuhnya tinggi menyebabkan proses oksidasi tidak mudah terjadi sehingga tidak mudah tengik. Namun jika kualitas minyak kelapa murni (virgin coconut oil) rendah, proses bau menjadi tengik akan berjalan lebih awal.

Dari minyak kepala murni (virgin coconut oil) dengan penambahan serai dan daun jeruk nipis, didapat minyak gosok sebanyak $400 \mathrm{ml}$ dan setelah diuji organoleptis sediaannya minyak gosok ini tidak menunjukan perubahan yang signifikan dari rasa, warna, bau dan bentuk, setelah 4 minggu, 6 minggu, dan 8 minggu sehingga masih bisa digunakan untuk minyak gosok masuk angin, keseleo, melembakan kulit kering dan pecah-pecah pada kulit. Beberapa tahap pembuatan minyak gosok:

Santan kelapa Sebelum Pengendapan
Warna : putih
Rasa : rasa
Bau : kelapa, batang serai dan daun
jeruk nipis
Bentuk : lengket dan licin

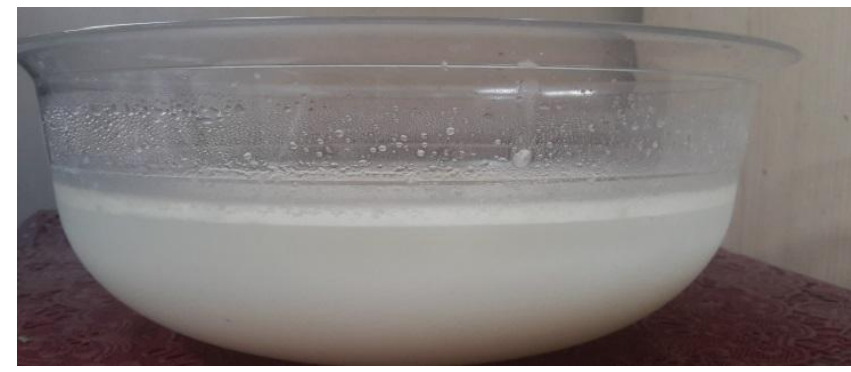

Gambar 1. Pengendapan Santan kelapa

\section{Proses Penyaringan santan menggunakan kain}

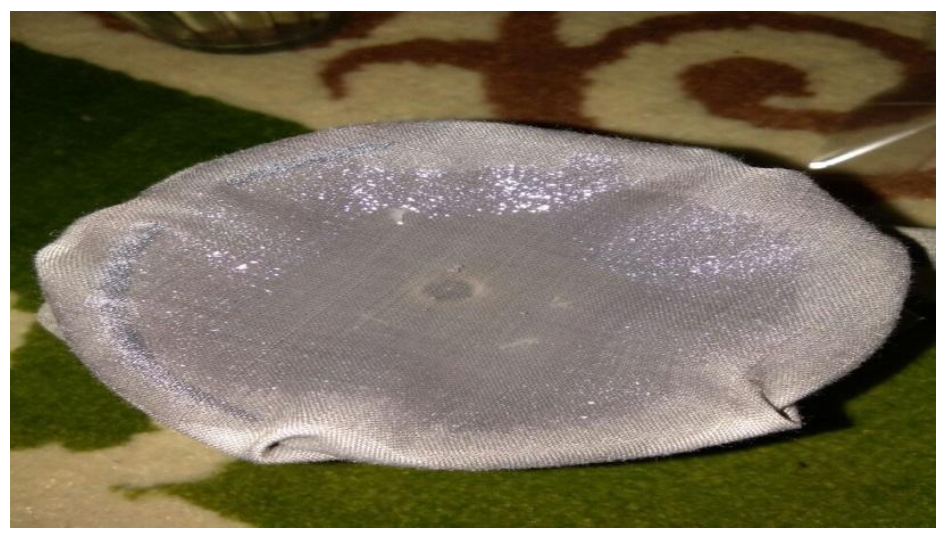

Gambar 2. Proses penyaringan 


\section{Proses perendaman VCO, batang serai dan daun jeruk nipis}

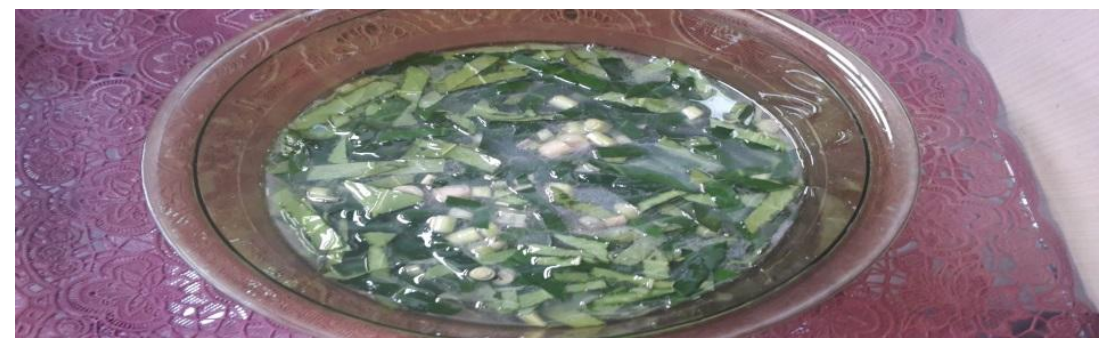

Gambar 2. Rendaman VCO, batang serai dan daun jeruk nipis

\section{Hasil Sediaan Setelah Penyaringan VCO, Batang serai dan Daun Jeruk Nipis}

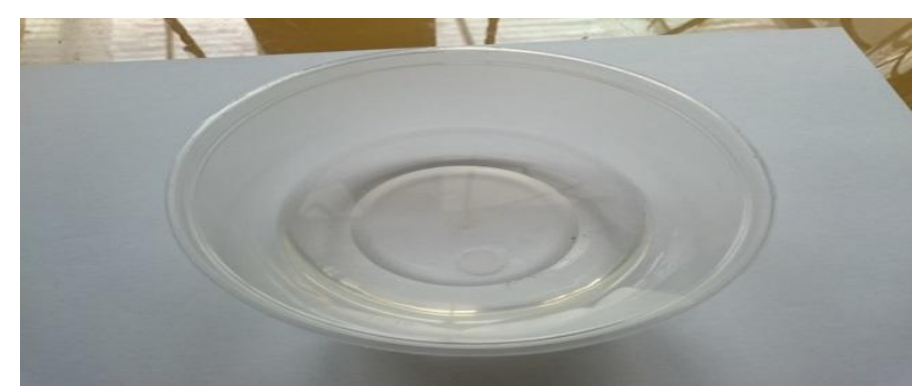

Gambar.1. Sediaan Minyak Gosok Setelah 8 Minggu.

Warna : bening

Rasa : hambar

Bau : kelapa, serai dan daun jeruk nipis

Bentuk : lengket dan licin

Dari hasil pengamatan sediaan setelah 4 minggu, 6 minggu dan 8 minggu menunjukan sediaan minyak gosok dari minyak kelapa murni (virgin coconut oil) dengan campuran serai dan daun jeruk nipis tidak ada perubahan dari warna, rasa, bentuk sedangkan bau serai dan jeruk nipis mengalami penurunan sedikit.

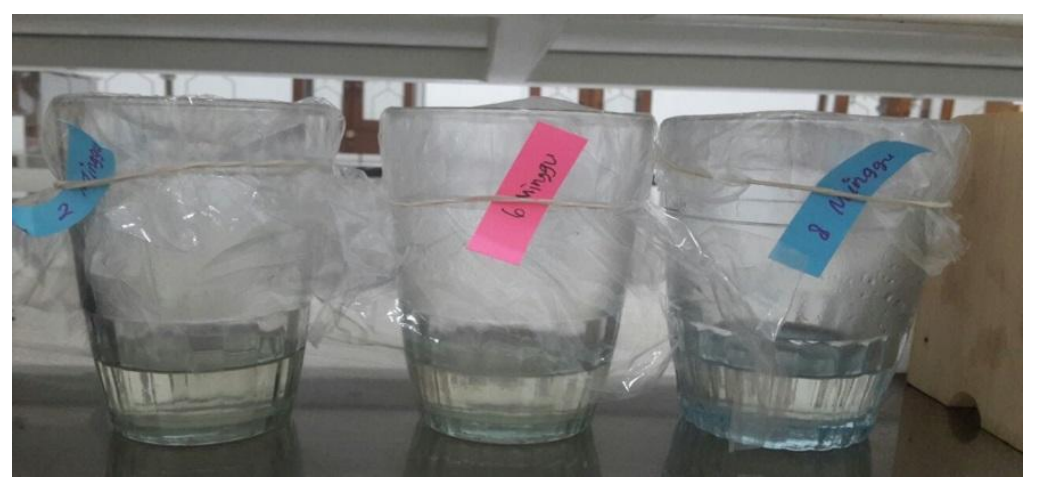

Gambar 2. Minyak gosok setelah 2 minggu, 4 minggu dan 8 minggu

Warna : bening

Rasa : hambar

Bau : kelapa, serai dan daun jeruk nipis

Bentuk : lengket dan licin

\section{SIMPULAN}

Berdasarkan hasil pengamatan yang diperoleh, dapat disimpulkan bahwa uji organoleptis fisik sediaan minyak gosok dengan metode pengendapan yang menggunakan bahan kelapa dengan campuran serai dan daun jeruk nipis mempunyai bentuk, rasa, warna yang sama setelah sediaan dibiarkan selama 4 minggu, 6 minggu dan 8 minggusedangkan untuk bau serai dan daun jeruk nipis mengalami perubahan, sehingga dapat disimpulkan bahwa penggunaan minyak gosok ini dapat stabil dan dinyatakan aman untuk digunakan karena dapat bertahan sampai dengan 8 minggu dengan penyimpanan dalam wadah tertutup. Minyak gosok ini tetap berwarna 
bening, memiliki rasa hambar dan licin dipermukaan kulit dapat digunakan sebagai minyak gosok, penyembuhan gejala masuk angin, gigitan serangga, atau bengkak, untuk melembabkan kulit kering serta pecah-pecah.

\section{DAFTAR PUSTAKA}

1. Bajry HA. Tubuh Anda Adalah Dokter Yang Terbaik. Purwakarta: Media Holistik Indonesia; 2010.

2. Tanka R, Andriani S, Helmiawati Y. Pembuatan Minyak Gosok Dari Bahan kelap (Cocos nucifera L.), Serai (Cymbopogon citratus DC.)dan Daun Dewa (Gynura segetum L.)dengan Metode Pengendapan Tradisional. Journal of Holistic and Health Sciences. 2016; 1(1).

3. Agusta,A. Minyak Atsiri Tumbuhan Tropika Indonesia. Bandung: Institut Teknologi Bandung; 2000. 29-30.

4. Soekarto ST. Penilaian Organoleptik untuk Industri Pangan. 2008. 34.

5. Sukmadinata. Metode Penelitian. Bandung: Rosdakarya; 2006. 